Журнал«Герспективита інновації наукиљ

(Серія«Гедагогіка», Серія«ГЕихологія», Серія«Медицина»

№4(4) 2021

УДК [37.015.3: 373.3$]-053.5$

https://doi.org/10.52058/2786-4952-2021-4(4)-114-127

Гавриленко Тетяна Леонідівна доктор педагогічних наук, професор кафедри дошкільної та початкової освіти, Чернігівський державний Національний університет імені Тараса Шевченка, вул. Гетьмана Полуботка, 53, м. Чернігів, е-mail: chnpu@ chnpu.edu.ua, тел: (0462) 941-170, https://orcid.org/ 0000-0001-9412-5805

Вінніченко Ірина Олексіївна магістрантка факультету дошкільної, початкової освіти і мистецтв, Чернігівський державний Національний університет імені Тараса Шевченка, м. Чернігів, вул. Гетьмана Полуботка, 53, тел.: (073) 128-37-95, e-mail: irinna.vinnichenko@gmail.com, https://orcid.org/00000003-3346-5683

\title{
ОРГАНІЗАЦІЯ ПСИХОЛОГО-ПЕДАГОГІЧНОГО СУПРОВОДУ ДІТЕЙ НА ЕТАПІ АДАПТАЦІї ДО ШКОЛИ
}

Анотація. У статті розглянуто феномен психолого-педагогічного супроводу дітей на етапі адаптації до школи, який автори тлумачать як особливий вид допомоги (або підтримки) дитині, що забезпечує ії розвиток в умовах освітнього процесу. Підкреслено, що в період адаптації дитини до школи змінюється звичний режим іiі дня, ігри змінюються уроками, дитина змушена підкорятися правилам шкільного життя, виконуючи вимоги вчителя.

Представлено розроблену програму психолого-психологічного супроводу процесу адаптації першокласників до навчання, яка забезпечуватиме реалізацію соціально-психологічних та педагогічних умов для успішного навчання i психологічного розвитку кожної дитини в шкільному середовищі. Як i Л.Талдонова, автори до найважливіших напрямів оптимізації адаптації молодших школярів до навчання відносить діагностичну, корекційнорозвивальну роботу, консультативно-просвітницьку діяльність.

Автори пропонують у консультативно-просвітницькій роботі з педагогічним колективом використовувати не лише психолого-педагогічні семінари, а й метод експертної оцінки та організаційні діалоги, які допоможуть учителям у виробленні тактики спілкування з дітьми, які переживають труднощі у адаптації, та їхніми батьками; у формуванні умінь організації педагогічної підтримки школярів; забезпечуватимуть актуалізацію та розширення уявлень педагогів про соціальну ситуацію розвитку першокласників, психологічні закономірності, механізми й особливості розвитку особистості, завдання і труднощі адаптації.

Критеріями ефективності реалізації програми психолого-педагогічного супроводу визначено: позитивну динаміку адаптаційних можливостей і стійкі 
результати корекційно-розвивальної роботи; підвищення рівня пізнавального розвитку і готовності першокласників до навчання у школі; підвищення психолого-педагогічної компетентності педагогів, нові ефективні форми роботи 3 дітьми та батьками; підвищення психолого-педагогічної компетентності батьків, активності батьківської громадськості в освітньому процесі.

Результати дослідження можуть бути використані для розробки рекомендацій з організації системи профілактичних і психокорекційних заходів, що забезпечують адаптацію першокласників до шкільного навчання в сучасній школі, яка буде ефективною, якщо педагоги нададуть психолого-психологічну підтримку через використання в роботі зрозумілих і близьких дітям методів навчання (ігрових i творчих), що сприятимуть процесу самореалізації i самоствердження.

Ключові слова: адаптація, психолого-педагогічний супровід, учні початкової школи.

Havrylenko Tetiana Leonidivna Doctor of Pedagogical Sciences, Professor of the Department of Preschool and Primary Education, Taras Shevchenko Chernihiv State National University, vul. Hetman Polubotko, 53, Chernihiv, e-mail: chnpu@ chnpu.edu.ua, tel: (0462) 941-170, https://orcid.org/0000-0001-9412-5805

Vinnichenko Iryna Oleksiivna Master's student of the Faculty of Preschool, Primary Education and Arts, Chernihiv State National University named after Taras Shevchenko, Chernihiv, st. Hetmana Polubotka, 53, tel .: (073) 128-37-95, e-mail: irinna.vinnichenko@gmail.com, https://orcid.org/0000-0003-3346-5683

\section{ORGANIZATION OF PSYCHOLOGICAL AND PEDAGOGICAL SUPPORT OF CHILDREN AT THE STAGE OF ADAPTATION TO SCHOOL}

Abstract. The article considers the phenomenon of psychological and pedagogical support of children at the stage of adaptation to school, which the authors interpret as a special kind of help (or support) for the child, which ensures its development in the educational process. It is emphasized that during the period of the child's adaptation to school the usual mode of his day changes, games change lessons, the child is forced to obey the rules of school life, fulfilling the requirements of the teacher.

The developed program of psychological and psychological support of the process of adaptation of first-graders to learning is presented, which will ensure the implementation of socio-psychological and pedagogical conditions for successful learning and psychological development of each child in the school environment. Like L. Taldonov, the authors include diagnostic, correctional and developmental work, consultative and educational activities among the most important areas of optimization of adaptation of junior schoolchildren to education. 
The authors propose to use not only psychological and pedagogical seminars, but also the method of expert assessment and organizational dialogues in consultative and educational work with the teaching staff, which will help teachers to develop tactics of communication with children experiencing difficulties and their parents; in the formation of skills of organizing pedagogical support for students; will provide actualization and expansion of teachers 'ideas about the social situation of first-graders' development, psychological regularities, mechanisms and features of personality development, tasks and difficulties of adaptation.

The criteria for the effectiveness of the program of psychological and pedagogical support are: positive dynamics of adaptation capabilities and sustainable results of correctional and developmental work; increasing the level of cognitive development and readiness of first-graders to study at school; increasing the psychological and pedagogical competence of teachers, new effective forms of work with children and parents; increasing the psychological and pedagogical competence of parents, the activity of the parent community in the educational process.

The results of the study can be used to develop recommendations for organizing a system of preventive and psychocorrective measures to ensure the adaptation of firstgraders to school in a modern school, which will be effective if teachers provide psychological and psychological support through the use of understandable and familiar to children ( game and creative) that will promote the process of selfrealization and self-affirmation.

Keywords: adaptation, psychological and pedagogical support, primary school students.

Постановка проблеми. Проблема адаптації першокласника до навчання в школі є однією з найважливіших для педагогіки та психології, оскільки від того, як дитина адаптується в школі, наскільки успішно пройдуть їі перші місяці і перший рік в освітньому закладі, залежить не тільки успішність ії навчання, ставлення до навчання, вчителя й однолітків, а й здатність до подальшого психічного, особистісного й соціального розвитку.

Початок навчання у школі - серйозне випробування для більшості першокласників. Вони повинні звикнути до нового колективу, до нових вимог, до повсякденних обов'язків, адаптуватися до нових умов. Соціальнопсихологічна адаптація представляє процес пристосування дитини до нових видів діяльності, відносин, вимог, нової системи соціальних умов і режиму життєдіяльності.

Незважаючи на достатню глибину наукових досліджень 3 означеної проблеми, число дезадаптованих першокласників у школі не зменшується, а в деяких випадках навіть має тенденцію до збільшення [8, с.13].

Як констатує А.Ніська, динаміка соціального життя викликає збільшення кількості стресових ситуацій, а отже, i підвищення рівня емоційного неблагополуччя. Проблема посилюється тим, що найчастіше батьки, вчителі 
початкових класів та інші дорослі, усвідомлюючи труднощі, не надають цьому великого значення, вважаючи, що з вирішенням конкретної ситуації емоційний дискомфорт першокласника зникне [6, с. 56].

3 цих позицій розробка програми психолого-психологічного супроводу процесу адаптації першокласників до навчання набуває актуальності, оскільки забезпечуватиме реалізацію соціально-психологічних та педагогічних умов для успішного навчання і психологічного розвитку кожної дитини в шкільному середовищі.

Аналіз останніх досліджень і публікацій. Цінними для нашої роботи виявилися дисертаційні дослідження О.Санькової, яка обгрунтувала психоогопедагогічні умови адаптації дітей молодшого шкільного віку до навчання в початковій школі [8]; А. Ліфінцевої, яка схарактеризувала особливості соціально-психологічної адаптації до школи дітей 3 хронічними соматичними захворюваннями [4]; Л.Гольцової, яка установила взаємозв'язок між самооцінкою i навчальною мотивацією в процесі адаптації першокласників до школи [3]; Л.Талдонової, яка вивчала соціально-психологічні особливості адаптації молодших школярів з обмеженими можливостями до навчання [9] та ін.

Отже, об’єктивна необхідність розв'язання проблеми адаптації дітей молодшого шкільного віку до навчання та недостатність розробок у цьому напрямі зумовили вибір теми «Організація психолого-педагогічного супроводу дітей на етапі адаптації до школи».

Мета статті. Головною метою нашого дослідження $є$ представити розроблену програму соціально-психологічного супроводу процесу адаптації першокласників до навчання.

Виклад основного матеріалу. Цілком очевидно, що для школи та ii соціально-педагогічної і психологічної служби завдання побудови ефективної системи психолого-педагогічного супроводу дітей у період адаптації до школи $\epsilon$ першочерговим.

Психолого-педагогічний супровід у сучасних дослідженнях розглядають як особливий вид допомоги (або підтримки) дитині, що забезпечує іiі розвиток в умовах освітнього процесу [9, с.143].

Повноцінний розвиток учня на усіх щаблях шкільного життя складається 3 двох складових: реалізація тих можливостей, які дитині відкриває даний етап вікового розвитку; реалізація тих можливостей, які пропонує ій дане соціальнопедагогічне середовище.

Звичайно, ці дві складові не повинні суперечити одна одній, а узгоджуватися, взаємодоповнюватися. Привести їх у відповідність - завдання усього педагогічного колективу. Але особлива роль тут належить педагогупсихологу. Тому психолого-педагогічний супровід - це ще й метод роботи педагога-психолога, який представляє собою цілісну, системно організовану діяльність. Ця робота є однією з найбільш складних, оскільки протікає всередині соціальних систем і предметом ii $\epsilon$ ситуація розвитку дитини як система ii 
Журнал«Герспективита інновації науки

(Серія«Гедагогіка», Серія «Гиихологія», Серія «Медицинв»

№4(4) 2021

стосунків зі світом, оточуючими дорослими і однолітками, 3 самою собою. Психолог повинен визначати не тільки програму своєї власної діяльності, а й діяльності всіх взаємодіючих соціокультурних систем. Це вимагає від педагогівпсихологів поряд $з$ діагностичними, консультативними і корекційним вміннями здатності до системного аналізу проблемних ситуацій та проєктування діяльності, спрямованої на їх вирішення. Останнє неможливе без відповідного (методологічного) забезпечення.

Ідею супроводу як втілення гуманістичного та особистісно-орієнтованого підходів послідовно і детально розробляли М.Бітянова [2], О.Александровська [1] та ін. у трьох основних площинах: ціннісно-смисловій підставі методу супроводу; організаційній моделі супроводжувальної діяльності; змісті та технології психологопедагогічного супроводу.

Для сучасних систем психолого-педагогічного супроводу характерні наступні організаційні принципи, також складові його методологічної бази: комплексний, міждисциплінарний, інтегративний підхід до вирішення будь-якої проблеми розвитку дитини; рівнозначність програм супроводу дитини в проблемній ситуації і програм попередження виникнення проблемних ситуацій; гарантія безперервного супроводу розвитку дитини в освітньому процесі; інформаційне та діагностичне забезпечення процесу супроводу; необхідність соціально-педагогічного та психологічного проєктування в супроводжувальній діяльності; рефлексивно-аналітичний підхід до процесу i результату психолого-педагогічного супроводу; орієнтація на роботу в сучасному правовому полі.

Розроблена нами програма психолого-педагогічного супроводу оптимізації адаптації молодших школярів до навчання грунтується на ідеях Л.Талдонової, яка до найважливіших напрямів оптимізації адаптації відносить діагностичну, корекційнорозвивальну роботу, консультативно-просвітницьку діяльність [9, с.143].

Основними завданнями консультативно-просвітницької роботи педагогів в контексті психолого-педагогічного супроводу адаптації дитини до школи визначено наступні: консультування вчителів щодо психолого-педагогічних проблем розвитку молодших школярів, щодо принципів і методів профілактики дезадаптації; ознайомлення педагогічного колективу закладу та поглиблення їхніх знань про умови адаптації дітей до школи та методи діагностики адаптації та адекватної самооцінки; координування діяльності колективу педагогів у забезпеченні умов для ефективного перебігу адаптаційних процесів першокласників до навчання; вивчення психологічного та соціального статусу кожного учня; визначення шляхів діяльності колективу 3 дітьми, які мають частковий і недостатній рівні адаптації та неадекватну самооцінку; ознайомлення з методами допомоги та підтримки школярам, які мають адаптаційні труднощі.

Основні напрямки консультування i просвіти педагогів визначаються необхідністю вирішення наступних завдань психолого-педагогічного супроводу:

- створення умов для соціально-психологічної адаптації дітей в школі; 
- адаптація навчальної програми, навантаження, освітніх технологій до вікових та індивідуально-особистісних можливостей і потреб учнів;

- підвищення рівня психологічної готовності дітей до успішного навчання, засвоєння знань, пізнавального розвитку.

Завдання психологічного консультування і освіти педагогів:

- актуалізація та розширення уявлень (знань) педагогів про соціальну ситуацію розвитку першокласників (молодших школярів), психологічні закономірності, механізми і особливості розвитку особистості, завдання i труднощі адаптації;

- допомога в організації методичної роботи педагогів, спрямованої на побудову навчального процесу відповідно до індивідуальних особливостей і можливостей школярів, виявленої в ході діагностики готовності до шкільного навчання і моніторингу адаптації дитини до школи;

- вироблення єдиної системи вимог до класу з боку різних педагогів, які працюють 3 класом і єдиного підходу до окремих дітей, тактики спілкування з дітьми і батьками;

- допомога в організації педагогічної підтримки школярів, розвиток здібностей педагогів з іiї надання.

Зміст (тематика) освітньої та консультативної роботи, так само як і форми іiі проведення, можуть бути досить різноманітними і розрахованими не на один рік роботи 3 педагогами. Наведемо приклади найбільш актуальних тем для психолого-педагогічного семінару: «Адаптація до школи. Попередження і подолання дезадаптації», «Психологічне здоров'я особистості і їі адаптованість», «Вікові особливості молодшого школяра», «Особливості прояву кризи 7 років», «Готовність до школи: фізіологічна, соціальна, психологічна», «Психологічний статус школяра: орієнтири для розвитку», «Несприятливі варіанти розвитку молодшого школяра», «Психологічний клімат школи (класу) як фактор розвитку особистості», «Умови та засоби створення дитячого колективу», «Відмітка та оцінка. Їх роль в розвитку молодшого школяра», «Організація «ситуації успіху» на уроці та в позаурочній діяльності», «Гра на уроці і після. Особливості ігрової взаємодії» та ін.

Слід зауважити, що така освітня консультативна робота може стати затребуваною лише в тому випадку, якщо вона буде включена в реальне шкільне життя. Лекції з психології та педагогіки, навіть прочитані найкращим майстром слова, зможуть викликати, як правило, тільки хвилину пожвавлення. Психологопедагогічні знання будуть включені в реальну професійну діяльність тоді, коли вони можуть бути засвоєні та включені в систему мислення педагога.

3 цією метою може бути використаний метод експертної оцінки. Експертна оцінка, зібрана в усіх педагогів (або у певної групи педагогів), дає ясну картину ïх думки з того чи іншого питання. Предметом експертної оцінки може бути, наприклад, психологічна атмосфера в педагогічному колективі, особистіснорозвивальний потенціал шкільного уроку, бажані досягнення учнів того чи 
Журнал«Герспективита інновації наукиљ

(Серія«Гедагогіка», Серія «Геихологія», Серія«Медицин»

№4(4) 2021

іншого віку та ін.

Алгоритм роботи за методом експертної оцінки:

1. Вибір предмета дослідження.

2. Опитування вчителів у вільній формі.

3. Категоризація відповідей (виділення декількох основних блоків відповідей).

4. Ранжування отриманих категорій (друге опитування вчителів).

5. Виявлення ієрархії категорій відповідей (отримання i опис колективної точки зору з предмета дослідження).

6. Проведення семінару 3 педагогами за результатами опитування.

7. Додаткові практичні заходи (складання обгрунтованої програми діяльності за результатами дослідження, порівняння отриманих в даній групі даних 3 даними іншої групи педагогів) [1, с. 64].

Ще одним досить універсальним методом психолого-педагогічної освіти педагогів, який реалізує діяльнісний підхід в освіті, є метод оргдіалогу. Цей метод і його сучасні модифікації перетворюють освітянина з пасивного слухача в суб'єкт навчання, який навчає інших.

Алгоритм проведення роботи з учителями початкової школи за методом оргдіалогу:

1. Група педагогів (зазвичай це усі вчителі початкової школи) об'єднується у мікрогрупи по 3-4 людини, у яких кожен отримує свій текст i завдання для роботи над текстом. Наприклад, це можуть бути завдання: скласти запитання до тексту; виділити ключові поняття; структурувати текст за запропонованою схемою; зробити висновки на основі тексту; підготувати пам'ятки й рекомендації та ін.

2. Індивідуальна робота педагогів над текстом у мікрогрупах. Педагоги запрошують у нові мікрогрупи з однаковими текстами. У цих мікрогрупах йде обмін інформацією та взаємонавчання. Колективно виконуються завдання за текстом. Потім учителі повертаються в початкові мікрогрупи, триває колективна робота над спільною темою.

3. Загальногрупова робота. Виступи представників від мікрогруп. Зіставлення продуктів діяльності груп з авторськими науковими (або науковопопулярними, текстами), рекомендації психолога.

4. Рефлексія [там само, с.103].

Метод оргдіалогу використовувався нами для підвищення психологопедагогічної компетентності учителів у питаннях надання педагогічної підтримки школярам, у яких є проблеми з адаптацією та самооцінкою.

Для підготовки текстів, що вивчаються в оргдіалозі, ми використовували книгу Є.Лютової, Г.Моніної «Шпаргалка для дорослих» [5]. Текст книги науково-популярного i практико-орієнтованого характеру, добре 
структурований, об'єднаний тематично у проблеми «Гіперактивні діти», «Тривожні діти», «Агресивні діти», «Аутичні діти», містить практичні рекомендації (шпаргалки) для дорослих і набори ігор і психологічних вправ для дітей.

Відповідно до тексту пропонували завдання для мікрогруп: дати визначення ключового поняття, описати основні прояви психологічного явища, виділити його можливі причини і наслідки, запропонувати рекомендації та / або пам'ятки дорослим з профілактики та подолання психологічного синдрому, запропонувати корекційно-розвивальні ігри та вправи, провести одну 3 ігор 3 учасниками оргдіалогу.

При роботі над текстами за методом оргдіалогу у педагогів розвивається вміння розуміти і структурувати текст, вони активно опановують матеріалом, що вивчається (через позицію навчання i активного діалогу), тренують навички публічного виступу, пошуку інформації від бесіди з іншими, краще усвідомлюють (на власному досвіді) переваги діалогу та полілогу в навчанні над монологом.

Напередодні прийому дітей до школи i їх первинної адаптації можна виділити типи консультаційних ситуацій. Пропонуємо одну з них.

Консультування з питань організації педагогічної підтримки дітей в період первинної адаптації. Допомогти дітям адаптуватися в колективі, виробити норми i правила спілкування, освоїтися в новому просторі, відчути себе в ньому комфортно - завдання, перш за все, класовода. Існує безліч розроблених програм організації такої підтримки. Найбільш відома програма, яка детально розкриває цю тему в роботі 3 першокласниками: Г.Цукерман, К.Поліванова «Вступ до шкільного життя» [7] (курс розрахований на перші два тижні навчання в класах розвивального навчання).

Педагогам, як правило, вона відома. Проте ми вважаємо за необхідне щорічне проєктування адаптаційного періоду, яке найбільш інтенсивно здійснюється в перші 3-5 днів перебування дітей в школі.

Для цього важливо створити доброзичливу атмосферу взаємодії в класі, познайомити дітей один з одним, з учителями, зі школою і шкільними правилами, що має сприяти зняттю тривожності. Для першокласників дуже важливо «вжитися» в позицію школяра (тому необхідно показати відмінність: школяр - НЕ школяр), освоїти організаційні навички та вміння для навчання в школі. Це, перш за все, основні правила поведінки на уроці, навички індивідуальної та колективної роботи, організація зворотного зв'язку з учителем, навички самооцінки і співвіднесення іiі 3 оцінкою іншого (дорослого або однолітків) та ін.

Щоб адаптаційний період був ефективним, необхідні наступні етапи його організації:

- розробка психологом та вчителем зразкового варіанта програми адаптаційного періоду і / або алгоритму (логіки) його проведення;

- усвідомлення педагогами ідеї адаптаційного періоду і прийняття його сенсу; 
Журнал«Герспектияитаінновації науки

(Серія«Гедагогіка», Серія «Гцихологія», Серія«Медицина»

№4(4) 2021

- створення класоводами програми адаптаційного періоду 3 урахуванням специфіки класу i власних можливостей на основі базової програми;

- забезпечення директором школи і його заступником організаційних умов для проведення адаптаційного періоду (наказ по школі, надання кабінетів для роботи, зміна розкладу і т.д.);

- залучення до проведення адаптаційного періоду фахівців (вчителів фізкультури, музики, бібліотекаря та ін.) для проведення тих чи інших колективних творчих справ;

- проміжний аналіз і коригування програми психологом, класоводами відповідно до виявлених психологічних особливостей дітей;

- узагальнення класоводами матеріалів індивідуальної та колективної роботи дітей та представлення результатів учням і батькам (це можуть бути малюнки, вироби, проєкти, перші сторінки «літопису класу», відеоматеріали про перші дні дітей у школі);

- проведення батьківських зборів для з'ясування очікувань батьків у зв'язку з навчанням їхньої дитини в школі і ознайомлення 3 підсумками та матеріалами адаптаційного періоду;

- підсумковий аналіз результатів адаптаційного періоду психологом, педагогами, визначення психолого-педагогічних завдань для кожного конкретного класу.

Пропонуємо приблизний план проведення адаптаційного періоду для першокласників.

День перший: Урочиста лінійка «Свято першого дзвоника». Виховна година «Здрастуй, школо !».

День другий:

Знайомство дітей з учителем і між собою. Шкільне приладдя.

Форми усної відповіді (індивідуальні, колективні - хорові, ланцюжком). Початок організації груп. Правило кола.

Екскурсія по школі (може бути в формі гри-подорожі «Пошук скарбу», де разом зі «скарбом» (подарунками для дітей) знаходиться «Наказ першокласнику від директора школи» або завдання на майбутні дні адаптаційного періоду та ін.).

День третій: Знайомство. Уміння висловлювати свої емоції. Парна форма роботи. Співробітництво. Шкільні правила ввічливості.

День четвертий: Знайомство. Уміння висловлювати свої думки. Зворотній зв'язок на уроці. Орієнтування на аркуші паперу. Дії за інструкцією.

День П’ятий: Знайомство. Протиріччя «люблю - не люблю». Вихід зі спірних ситуацій. Критерії самооцінки і оцінки. «Чарівні линієчки». Свято «Посвята в учні».

Значна увага у межах програми соціально-психологічного супроводу процесу адаптації дітей молодшого шкільного віку до навчання повинна надаватися також корекційній роботі з сім'єю. 
Неможливо розібратися в проблемах і труднощах дитини без розуміння сімейного контексту іiї життя. Контекстом, що визначає можливість виникнення шкільної дезадаптації дитини, тих чи інших порушень в іï особистісному розвитку, $\epsilon$ сім'я як система внутрішньосімейних стосунків та родинного виховання. Аналіз результатів психодіагностики готовності дітей до шкільного навчання, моніторингу процесу адаптації першокласників до школи показує, що серед причин «важкої» адаптації, стійкої дезадаптації першокласників на перший план виходять: соціальна та педагогічна занедбаність на попередніх етапах розвитку, тривала і масивна психічна депривація тих чи інших потреб дитини в сім'ї, емоційні розлади і соматичне ослаблення внаслідок конфліктних відносин в сім'ї та недоцільного стилю виховання.

На будь-якому етапі вікового розвитку дітей освітній заклад i його психолого-педагогічна служба вирішують такі завдання у взаємодії з сім'єю: сім'ï.

1. Діагностика сім'ї, вивчення умов і факторів розвитку дитини в

2. Інформування батьків про діяльність освітнього закладу, його цілі, завдання, програми навчання і виховання, хід та результати педагогічного процесу.

3. Психолого-педагогічна освіта, навчання та виховання батьків, розвиток їх батьківської компетентності.

4. Включення батьків у спільну з педагогами і дітьми діяльність, створення дитячо-дорослих форм спільності.

5. Розвиток ініціативи і суб'єктної позиції батьків, допомога у створенні та організації діяльності громадських формувань батьків.

6. Психолого-педагогічна допомога в корекції факторів сімейного виховання, несприятливих для розвитку дитини.

На початку шкільного навчання, у 1-му класі і під час усього періоду початкової освіти, у педагогів і психологічної служби $\epsilon$ досить багато можливостей i шансів налагодити ефективну взаємодію 3 сім'єю, залучити батьків до психолого-педагогічного супроводу адаптації дітей до школи.

Пріоритетними для педагога та психолога є такі завдання:

- $\quad$ встановлення доброзичливого контакту, створення довірливих стосунків з батьками;

- $\quad$ підвищення психологічної компетентності батьків з тих питань, які найбільш актуальні з точки зору періоду розвитку учнів;

- у усвідомлення батьками певної відповідальності за те, що відбувається з їхньою дитиною в школі.

Якщо цього вдалося домогтися, можна розраховувати на співпрацю 3 батьками у вирішенні проблемних для дитини ситуацій.

Що ж стосується форм роботи, вони можуть бути як традиційними (батьківські збори, групові та індивідуальні консультації), так і порівняно новими (батьківські клуби, соціально-психологічні тренінги, психолого-педагогічний театр). 
Журнал«Герспективитаінновації науки»

(Серія«Гедагогіка», Серія«Гцихологія», Серія«Медицинв»

№4(4) 2021

На початку шкільного навчання в 1-му класі батьківські збори й зустрічі бажано проводити регулярно - приблизно раз на місяць, обговорюючи з батьками труднощі адаптаційного періоду, розповідаючи про форми підтримки дитини, оптимальні домашні форми рішення шкільних проблем і т.д. У змістовому відношенні коло обговорюваних питань у взаємодії з батьками може бути дуже різноманітним.

Яскравим прикладом інтеграції освітнього процесу, який грунтується на співпраці педагога і психолога 3 батьками, є батьківський клуб «Адаптація дитини до школи». Основними цілями створення і організації діяльності батьківського клубу є підвищення психологічної компетентності батьків, що сприяє оптимізації дитячо-батьківських відносин, створенню умов для емпатійно-особистісного спілкування між членами сім'ї, формуванню установки на співпрацю зі школою з метою успішного навчання, виховання і розвитку особистості дитини. Проведення засідань батьківського клубу передбачає вирішення відразу декількох завдань, що виходять 3 функцій клубу: просвітницької, прогностичної, діагностичної, консультативної, розвиваючої, корекційної.

Методи, які використовуються в роботі клубу «Адаптація дитини до школи»:

•експрес-діагностика емоційних станів, знань, стосунків та цінностей батьків;

•лекції та повідомлення фахівців з заявлених тем (педагог-психолог, логопед, лікар, музичний працівник та інші фахівці);

•експресивні методи творчого самовираження в рухах, у малюнках, у письмових і творчих роботах;

-методи соціально-психологічного і педагогічного тренінгу: дискусійне обговорення різних психологічних проблем і педагогічних ситуацій, психогімнастика, ігрове моделювання, ігри та вправи різної спрямованості, психологічні етюди;

•обмін досвідом у вихованні дітей;

•аналіз продуктів діяльності дітей, результатів педагогічної та психологічної діагностики.

Пропонуємо такий варіант тематики клубних зустрічей: «Давайте познайомимося ближче. Сім'я і школа - тепер ми разом», «Види батьківської любові. Як насправді любити дитину», «Світ дитини і дорослого (спільна зустріч дітей і батьків). Чому дитина буває нещасливою?», «Наше здоров'я у наших руках (спільна зустріч дітей і батьків)», «Гра - справа серйозна. Ігри в школі i сім'і»», «Світ наших захоплень (спільна зустріч дітей і батьків)» та ін.

Досвід організації та здійснення діяльності батьківських клубів 3 перших кроків вступу дитини до школи показує, що така форма взаємодії з батьками сприяє гармонізації, взаємодоповнюваності впливів дорослих на соціальну ситуацію розвитку школяра, дозволяє встановити партнерську зацікавленість 
один в одному у ставленні педагогів і батьків, пробуджує стійкий інтерес батьків не тільки до питань виховання і розвитку дітей, але в цілому до психологопедагогічного знання, стимулює прагнення до самопізнання i зміни неефективних батьківських установок.

Важлвим напрямом оптимізації в період адаптації дітей до школи є також психологічна корекційно-розвивальна робота.

Корекційно-розвиваюча робота в закладі освіти являє собою сукупність психолого-педагогічних впливів, які передбачають або виправлення, або профілактику недоліків і відхилень у розвитку дитини. Відповідно, корекційнорозвиваюча робота з дітьми в період адаптації дітей до школи являє собою сукупність психолого-педагогічних впливів, які передбачають профілактику i подолання шкільної дезадаптації, яка може проявлятися на фізіологічному, пізнавальному, соціально-психологічному та особистісному рівні [1, с. 25].

Корекційна робота допомагає долати труднощі розвитку дитини, розвивальна - спрямована на профілактику і попередження проблем розвитку.

Корекційно-розвивальна робота повинна будуватися не як просте тренування умінь і навичок, не як окремі вправи 3 вдосконалення психічної діяльності, а як цілісна осмислена діяльності дитини, яка органічно вписується в систему їі повсякденних життєвих відносин.

Мета корекційно-розвивальної роботи на етапі адаптації дітей до школи, сформульована в найзагальнішому вигляді: формування i розвиток психічних процесів і навичок дітей, що сприяють успішній адаптації першокласників в ситуації шкільного навчання.

Досягнення цієї мети можливе, як вважають багато фахівців, в процесі реалізації наступних завдань:

1. Формування стійкої навчальної мотивації на тлі позитивної «Яконцепції» дітей, стійкої самооцінки і низького рівня тривожності.

2. Розвиток у дітей соціальних і комунікативних умінь, необхідних для встановлення міжособистісних відносин 3 однолітками і відповідних рольових відносин з педагогами.

3. Розвиток у дітей когнітивних умінь і здібностей, необхідних для успішного навчання в початковій школі. Комплекс цих умінь і навичок входить до поняття психологічної готовності до школи [2, с.64].

Очевидно, що ці завдання повинні розглядатися в комплексі, так як тільки цілісний вплив на особистість дитини може сприяти стійкій позитивній зміні або формуванню певних психологічних феноменів.

Наприклад, корекційно-розвивальна робота в сфері когнітивного розвитку першокласників може припускати: розвиток сприйняття і сенсорних здібностей; розвиток пізнавальних процесів: уваги, пам'яті, мислення; розвиток уяви i творчих здібностей; становлення понятійного апарату i основних розумових операцій: вміння виділяти суттєві ознаки, аналізу, порівняння, встановлення причинно-наслідкових зв'язків, узагальнення; корекція і розвиток мови і мовних 
Журнал «Герспективита інновації наукњ

(Серія«Гедагогіка», Серія «Гиихологія», Серія «Медицин»

№4(4) 2021

функцій; корекція і розвиток просторової організації, координації рухів і дрібної моторики; розвиток пізнавальної мотивації і т.д.

Однією 3 найважливіших проблем психолого-педагогічного супроводу процесу адаптації дітей до школи $є$ проблема прийняття дитиною нової соціальної ролі, розвиток іiї позитивної Я-концепції, формування стійкої навчально-пізнавальної мотивації. Вирішення цієї проблеми пов'язано 3 реалізацією наступних завдань корекційно-розвивальної роботи:

- розвиток емоцій і способів безпечного емоційного реагування;

- $\quad$ корекція страхів і зниження тривожності;

- $\quad$ формування позитивного ставлення до школи, навчання;

- $\quad$ вироблення адекватного ставлення до помилок і невдач;

- формування ефективного адаптаційного стилю і здатності долати труднощі;

- $\quad$ формування прагнення до реалізації своїх здібностей та інші завдання.

Основний зміст корекційно-розвивальних занять складають ігри та психотехнічні вправи. Ми у цьому дослідженні не вважаємо за необхідне наводити приклади таких ігор та вправ (їх в сучасній літературі представлено дуже багато). Однак думаємо, що корисним буде зазначити вимоги-рекомендації щодо змісту корекційно-розвивальної роботи, розроблені М.Бітяновою [2], які варто використати. Пов'язані з розробленими нею ж параметрами психологопедагогічного статусу, ці вимоги дозволяють реалізувати принцип системності й забезпечити комплексність корекційно-розвивальної роботи.

Висновки. Отже, психолого-педагогічний супровід ми розглядаємо як особливий вид допомоги (або підтримки) дитині, що забезпечує ï розвиток в умовах освітнього процесу. Розроблена нами програма психолого-педагогічного супроводу оптимізації адаптації молодших школярів до навчання враховує ідеї Л.Талдонової, яка до найважливіших напрямів оптимізації адаптації відносить діагностичну, корекційно-розвивальну, консультативно-просвітницьку діяльність. Плановані результати програми:

1. Успішна адаптація учнів 1-х класів до процесу шкільного навчання.

2. Формування і розвиток пізнавальних процесів учнів i, як наслідок, підвищення навчальної мотивації і потреби в отриманні знань.

3. Високий рівень професійної компетентності і мотивації педагогів в межах здійснення психолого-педагогічного супроводу.

4. Психолого-педагогічна компетентність батьків з питань адаптації дитини до школи.

\section{Лimepamypa:}

1. Александровская Э. М. Психологическое сопровождение школьников: учеб. пособие для студентов высш. пед. учеб. заведений / Э. М. Александровская, Н. И. Кокуркина, Н. В. Куренкова. М.: Академия, 2002. 206 с. 
2. Битянова М. Р. Адаптация ребенка в школе: диагностика, коррекция, педагогическая поддержка. М.: Владос, 2002. 112 с.

3. Гольцова Л. Н. Взаимосвязь самооценки и учебной мотивации в процессе адаптации первоклассников к школе: автореф. дисс. ... канд. псих. наук. спец.: 19.00.13. Москва, 2005. 24 с.

4. Лифинцева А. А. Особенности социально-психологической адаптации к школе детей с хроническими соматическими заболеваниями: автореф. дис. ... канд. псих. наук. спец.: 19.00.13. Москва, 2005. 24 с.

5. Лютова Е. К., Монина Г. Б. Психокоррекционная работа с гиперактивными, агрессивными, тревожными и аутичными детьми. Шпаргалка для родителей. СПб.: Речь, 2007. 136 с.

6. Нисская А.К. Особенности адаптации к школе современных первоклассников. Вестник МГОУ. Серия : Психологические науки. 2012. № 3. С. 55 - 62.

7. Цукерман Г.А., Поливанова К.Н. Введение в школьную жизнь. М.: Просвещение, 1994. 33 c.

8. Санькова О. А. Психолого-педагогические условия адаптации детей младшего школьного возраста к обучению в начальной школе: автореф. дис. ... канд. пед. наук. спец.: 13.00.01. Москва, 2006. 23 с.

9. Талдонова Л. О. Соціально-психологічні особливості адаптації молодших школярів 3 обмеженими можливостями до навчання: дис. ... канд. псих. наук. спец.: 19.00.05. Сєвєродонецьк, 2020. 246 с.

\section{References:}

1. Aleksandrovskaya, E. M. (2002). Psihologicheskoe soprovozhdenie shkolnikov [Psychological support of schoolchildren]. Moscow: Akademiya [in in Russian].

2. Bityanova, M. R. (2002). Adaptatsiya rebenka v shkole: diagnostika, korrektsiya, pedagogicheskaya podderzhka [Adaptation of the child at school: diagnostics, correction, pedagogical support]. Moscow: Vlados [in in Russian].

3. Goltsova, L. N. (2005). Vzaimosvyaz samootsenki i uchebnoy motivatsii v protsesse adaptatsii pervoklassnikov $\mathrm{k}$ shkole [The relationship between self-esteem and learning motivation in the process of adaptation of first-graders to school]. Extended abstract of candidate's thesis. Moscow: IPRAN [in in Russian].

4. Lifintseva, A. A. (2005). Osobennosti sotsialno-psihologicheskoy adaptatsii k shkole detey s hronicheskimi somaticheskimi zabolevaniyami [Features of social and psychological adaptation to school of children with chronic somatic diseases]. Extended abstract of candidate's thesis. Moscow: IPRAN [in in Russian].

5. Lyutova, E. K., \& Monina, G. B. (2007). Psihokorrektsionnaya rabota s giperaktivnyimi, agressivnyimi, trevozhnyimi i autichnyimi detmi. Shpargalka dlya roditeley [Psycho-correctional work with hyperactive, aggressive, anxious and autistic children. A cheat sheet for parents]. St. Petersburg: Rech [in in Russian].

6. Nisskaya, A.K. (2012). Osobennosti adaptatsii k shkole sovremennyih pervoklassnikov [Features of adaptation to school of modern first graders]. Vestnik MGOU. Seriya: Psihologicheskie nauki - MGOU Bulletin. Series: Psychological Sciences, 3, 55 - 62 [in in Russian].

7. Sankova, O. A. (2006). Psihologo-pedagogicheskie usloviya adaptatsii detey mladshego shkolnogo vozrasta $\mathrm{k}$ obucheniyu $\mathrm{v}$ nachalnoy shkole [Psychological and pedagogical conditions for the adaptation of primary school children to primary school]. Extended abstract of candidate's thesis. Moscow: IPRAN [in in Russian].

8. Taldonova, L. O. (2020). SotsIalno-psihologIchnI osoblivostI adaptatsIYi molodshih shkolyarIv z obmezhenimi mozhlivostyami do navchannya [Socio-psychological features of adaptation of junior schoolchildren with disabilities]. Extended abstract of candidate's thesis. Severodonetsk: SNU [in Ukrainian] 